\title{
Nigeria's Domestic Public Debts and Economic Development
}

\author{
${ }^{1}$ Opara Ihunna Victoria, ${ }^{2}$ Nzotta Samuel Mbadike and ${ }^{3}$ Kanu Success Ikechi \\ ${ }^{1,2}$ Department of Financial Management Technology, Federal University of Technology, Owerri \\ ${ }^{3}$ Department of Banking and Finance, Faculty of Social and Management Sciences, Eastern Palm \\ University, Ogboko Ideato,P.M.B 6, Orlu Imo State, Nigeria
}

\begin{abstract}
This study investigates the effect of Nigeria's domestic public debt on economic development of Nigeria spanning from 1981-2018. This is in response to the doubts being raised in some quarters as to whether the continuous increase in domestic debt over the years has led to the economic development of Nigeria as the former has been known to influence the later if well harnessed and executed. The secondary data used in the study were sourced from Central Bank of Nigeria Statistical Bulletin, Debt Management Office of Nigeria, World Bank Development Indicators and United Nations Development Program. The study made use of Ordinary Least Square Regression tools to determine the statistical relationship between Nigeria's domestic public debt profile and Human Development Index as well as private sector investment. The outcome of study in the first model showed that domestic debt servicing and state governments' domestic debts are significantly related to economic development. On the other hand, Federal domestic debt and State domestic debt are significantly related to private sector investment. The study therefore recommends that government should be cautious in her domestic borrowing policy given that servicing debt always becomes a burden to the sustainability of economic gains, in addition to its tendency of crowding-out private sector investment in Nigeria.
\end{abstract}

Keywords: Domestic Debts, Economic Development, Human Development Index, Debt Servicing, Private Sector Investment.

\section{Introduction}

\subsection{Background of the Study.}

To facilitate economic growth, developing nations like Nigeria are encouraged to borrow to beef up their limited stocks of capital and to bridge the domestic savings- investment gap. If the borrowed funds are effectively ploughed back and correctly exploited for fruitful investments, it will help to fast track the developmental strides and thus, raise the standard of living of her people. (Egbetunde, 2012).

There are several reasons why nations may need to borrow; one of such is to smoothen and hide fiscal deficits. This could spice up investments and hence accelerate economic process and development (Adam et al, 2016). By so doing, the economy is expected to grow and bring about a timely settlement of debts so incurred. If this cycle is upheld and repeated overtime, growth will influence per capita income which is a condition for poverty reduction (Amakom, 2003).

Contrary to the above expectations, it is pertinent we state here that, Nigeria's level of public debts seem to have reached an alarming proportion with not much on ground to show for it. The burgeoning level of public

7 
debt now constitutes a crucial element of economic agenda. Nigeria seems to have found itself in a situation where the magnitude of its debt profile and her ability to service the debts are posing as serious problems to the government. The debts appear to be accumulating at a reasonably rapid pace far more than the nation's capacity to repay. The seeming debt crisis has continued notwithstanding the policy measures aimed at bringing it under control. It has also brought with it an ever-increasing level of unemployment, heightened inflation, capacity underutilization, and over dependence on the oil sector among others. Succinctly put, Nigeria's debt stock is increasing without a clear and visible economic growth path, stability and development. It has become obvious that she may not attain the needed level of economic development without first taking into consideration the consequences of her debt burden on the economy. That is the essence of this study!

\subsection{Problem Statement}

In the past two decades, Nigeria has borrowed large amounts internally, often at highly concessional interest rates with the hope to accelerate development through higher investment, and thus foster economic growth. It is therefore noticeable that Nigeria's indebtedness has gone beyond reasonable limits required to realize desired goals and produce debt-free or less burden which will enhance economic process with a resultant enhancement in poverty level. Recent financial statistics showed that Nigeria's debt had been on the increase over time. According to the Debt Management Office, debt stock stood at N7.421 trillion bringing the total public debt to N8.5 trillion without state government debts, which stood at N1.6 trillion as at December 2013 and N7.42 trillion at the top of June 2014 as compared to N7.18 trillion at the top of first quarter of 2014, representing 3.3 percent upsurge in the first half of the year. This planetary increase has continued persistently as the debt rose to 12.58 trillion and 12.83 trillion in 2017 and 2018 respectively.

In spite of her continued penchant for loans, Nigerian economy is still characterized by low per capita income (one of the lowest in the world), high unemployment rates, dwindling economy, inadequate basic amenities, poor infrastructural development, falling growth rates of GDP and recently rated the poverty headquarters of the world. In addition, the Nigerian economy dipped into avoidable recession between 2016 and 2017, which is a testimony of poor management of borrowed funds.

The reliance by the federal government on borrowing from the banking industry, chiefly by the CBN, to finance its large and untenable fiscal deficits has affected the expansion of the Nigerian economy undesirably. This has delayed the attainment of macroeconomic stability and sustainable economic development in Nigeria. Additionally, it has jam-packed the private sector from the credit market, thereby delaying investment and output development.

Due to the identified continuous rise in Nigeria's debt profile without a clear and visible economic stability, reduction in poverty/ unemployment, and poor economic growth over the years, this study is designed to unravel how the ever-increasing public debts in Nigeria has influenced economic development in Nigeria for the period 1981 to 2018 . That is the problem of study.

\subsection{Objectives of the Study}

The broad objective of this study is to Investigate Nigeria's Public Debts and her level of Economic Development. The specific objectives are to ascertain the impact of:

-Federal debt on the economic development of Nigeria.

-Debt servicing on the economic development of Nigeria.

-State debt on the economic development of Nigeria.

-Federal debt on private sector investments in Nigeria.

-Debt servicing on private sector investments in Nigeria.

-State debt on private sector investment in Nigeria.

- Federal and State debts on economic development of Nigeria.

\subsection{Justification of Study}


The study will provide recommendations to policymakers that could assist in appraising the impact of domestic public debts on the economic development of Nigeria. It will also serve as reference material for future and further works on the impact of domestic public debts and its attendant effects on the economy. It will also provide a basis for further comparative studies, in both the developed and less developed economies.

\subsection{Scope of Study}

This study employed a time series data for the period of $1981-2018$. The choice of scope of study was informed by the fact that, this period witnessed a greater chunk of government's borrowings in Nigeria.

\section{Literature Review}

\subsection{Conceptual Framework}

Oshandami (2006) defined domestic debt as debt instrument issued by the federal government and denominated in local currency. In main beliefs, state and local government areas can issue debt instrument, but their capacity to issue such debt instrument must go with the treasury certificates, federal government development stock and treasury bonds. Out of these, treasury bills, treasury certificate and development stocks are merchandisable and traversable while treasury bonds paths and advances are not marketable but held exclusively by the central bank of Nigeria. Odozi (1996) in his study sees domestic debts as the gross obligation of government property which should include federal, state, and local government transfer obligation to the citizen and corporate firms within the country. Accordingly, the central bank of Nigeria $(\mathrm{CBN})$ as banker and financial counselor of the federal government is charged with the responsibility of handling the domestic public debt.

Domestic debt instruments also offer investors with an alternative striking avenue of investment and can therefore help in getting money from the non-monetary sector to the formal financial system (IMF, 2001). The paybacks go beyond savings mobilization and extend to the extending the financial market, broadening of the tax base and improved perceptions of currency and country risk (Abbas and Christensten 2007). Since banks in various developing countries burdened with risk and sometimes unpredictable business environment, they may be unwilling to engage with the private sector. However, holdings of government securities offer banks with stable and safe income and may therefore recompense for the poor environment and encourage lending to riskier sectors (Kumhof and Tanner, 2005). In the long run, rising domestic financing will help governments build a track record to access international markets as research has revealed that countries that have successfully issued sovereign bonds on international markets have characteristically had a long prior experience with issuing domestic government bonds in their domestic markets (Akahn, 2005).

Oyedeji (1985) think through debt as the resource or money in use in an organization which is not funded by its owner or does not in any way belong to them. It is a liability characterized by a financial instrument or other formal correspondent. In modern law, debt has no fixed meaning and may be viewed essentially as that which one person legally owes to another or an obligation that is enforceable by legal action to make payment of money. When a government acquires fund, the debt is a public debt. Public debts either internal or external are acquired by the government through borrowing for domestic reserves. Debts are categorized into two i.e. reproductive debt and dead weight debt. When a loan is acquired to enable the state or nation to buy some sort of assets, the debt is said to be reproductive e.g. money acquired for build factories, electricity refineries etc. Nevertheless, debt accepted to finance wars and for current expenditure are dead burden debts.

Likita, (2000) recognized debt as contractual obligation of acquiring fund with a promise to pay back at a future date. Every economy requires an amount of capital to engender production and sustain development: capital, being a factor of production is principally important but relatively scarce, and the scarcity of capital is much more predominant in developing countries like Nigeria.

\subsection{Domestic Debt Instruments}


Treasury Bills: These can be referred to as debt instruments used by the federal government to borrow money for short term of about three months pending the collection of its revenues. Treasury bills were first introduced in United Kingdom during the days of Walter Bagehot (1877), and at that time it was molded as commercial bills. In Nigeria, Treasury bill was introduced on the 19th day of March 1959 based on the strength of the Treasury bill Act of 1959, No. 11. The first public issue of Treasury Bills in Nigeria was made on April 7, 1960.

The success realized inspired further issues of this monetary instrument (Anyanfo, 1993). Presently, the allocations of treasury bills are issued by an auction-based system and in multiples of N1000.00 per tender. Ordinarily, contributions are sold through an authorized dealer.

Treasury Certificates: are medium-term government securities which have a maturity of within one to two years. It functions as link between treasury bills (short-term instruments) and long-term government stocks. Treasury certificates were introduced in Nigeria in the year 1968 and are similar to treasury bills in all admirations, except that the tenure is different. Both instruments are qualified for rediscount at the money market. Treasury certificates have played a key role in the growth of the money market in Nigeria. The instrument has also helped government in meeting its financial necessities, especially during the civil war years and the rebuilding period of the 1970's. Additional issues were suspended in 1975 due to excess liquidity in the system caused by the oil boom. The Treasury certificates were again announced in 1976 as a result of pressure on government finances.

Treasury Bonds: appeared towards the end of 1989 when the monetary authorities of Nigeria planned to convert N11.35 billion of maturing treasury bills into $5 \%$ denominated treasury bonds with maturity profile in excess of ten years. Treasury bonds came not as an outcome of issuance of new instruments but as an essential aspect of internal debt management strategy aimed at distending debt maturity profile. The idea behind this concept is that the instruments are not eligible to be traded at the money market and cannot serve as an instrument for open market processes. The main objective of treasury bonds is to provide a costeffective source of deficit financing for the government and seek to minimize debt service obligations in government debts prompted by the high level of deficit financing by the government (Nzotta, 2004).

Development Stock: is fairly long-term debt instruments sponsored by the CBN on behalf of the federal government. They have stable rates of return and well-defined maturity. In an effort to advance the liquidity and profitability of banks, the central bank classified government development stocks of less than 3 years of maturity as qualified liquid assets for the purpose of calculating the liquidity of banks. This move further widened the scope of activities in the money market (Nzotta, 2004).

FGN Bonds: are debts securities (liabilities) of the federal government of Nigeria issued under the authority of Debt Management Office (DMO) and recorded on the Nigerian Stock Exchange. The FGN has an obligation to pay the bondholder the principal and agreed interest as at when due. A bond holder has modestly lent to the federal government for a specified period of time. The FGN bond is measured as the safest of all investments in domestic currency securities market reason being that it is backed by the full faith and credit of the federal government. They have no default risk, since it is virtually certain that the interest and principal will be paid as they fall due. The income thus earned will be exempted from the state and local taxes. The minimum subscription of FGN Bond is N10,000.00 + multiples of N1,000.00 afterwards. Most FGN Bonds have fixed interest rates which are paid semi-annually. Tenure of an FGN Bond is for a minimum of two years. (www.dmo.gov.ng).

Promissory Notes: are documents affirming that a person promises to pay another a specified sum at a specified date. Since it is a traversable instrument, it is analogous to a bill of exchange. the federal government of Nigeria can raise domestic public loans by means of the Government Promissory Notes Act 1960 No. 6.

\subsection{Theoretical Framework}




\subsubsection{The Neoclassical Theory}

According to the neoclassical growth theory, debt has a direct consequence on economic growth. This is because if the amount borrowed was used optimally, it is anticipated to upturn investment. As long as countries use the borrowed funds for viable investments without suffering from macroeconomic instability, policies that distort economic incentives or sizable hostile shocks, growth should increase and allow for timely debt repayment. On the other hand, the indirect influence of debts is its effect on investment. The transmission mechanism through which debts affect growth is its decline in the resources available for investment by debt servicing. Also, public debt can act as an implicit tax on the resources produced by a country and create a burden on future generations which come in the form of abridged flow of proceeds from a lower stock of private capital. Consecutively, this may lead to an increase in long-term interest rates, a crowding out of private investments essential for productive growth, and a fall in capital accumulation.

\subsubsection{Post Keynesian Theories of Debt}

The Post-Keynesian theories of public debt had its experience from the huge rising public debt and the developed nation going through a phase of inflation and rise in price. Government expenditure also was rising at a speedy pace and non-developmental component of it was quite high. These recent theories of public debt invigorated the controversy of whether public debt is a burden and how to measure the burden of public debt. James. M. Buchanan's public principles of public debt (1958) defied the modern theories view that, public debt is not a burden on the economy and no matter how it is financed, it cannot be transferred to future generation. Meade and Musgrave (1959) also agreed to Buchanan's idea where he tried to prove that in the most general case that:

i. The primary real burden of a public debt is lifted to future generation;

ii. The analysis between public debt and private debt is necessarily correct;

iii. The external debt and internal debt are profoundly equivalent (Modigliani, 1964).

\subsubsection{Traditional View}

Domestic debt may have positive as well as negative effects on economic growth. In the traditional view, a tax cut sponsored by government borrowing would have many effects on the economy. The direct impact of the tax cut should be to encourage consumer spending. Higher consumer spending affects the economy both in the short-run and longer-run. In the short-run, higher consumer spending will increase the demand for goods and services and thus raise output and employment. As the marginal tendency to consume is higher than marginal tendency to save, the rise in private savings falls short of government dis-saving. This rises in the real interest rate of the economy had by extension encouraged capital inflow from abroad.

In the long-run, the higher interest rate could discourage savings and thus crowd out private investment. The lower domestic savings, the smaller the capital stock. The inflow from abroad would give rise to greater foreign debt. The higher aggregate demand, the higher the price level that adjusts over time, and the economy returns to a normal rate of output. The lower investment in the long run leads to a lower steady state capital stock and a lower level of output. Therefore, the overall effect when considering the long-run period would be smaller than total output, and finally lower consumption and reduce economic welfare. This is also referred to as the burden of public debt, as each generation burdens the next, by leaving behind traces of aggregate stock of capital (Sheikh et al. 2010).

\subsection{Empirical Evidence}

The necessity to meet up with the ever increasing demand for government investment in public infrastructure and other social goods is the major cause of the rapid increment in the Nigerian domestic debt stock. Several researchers at various times have conducted studies over the affiliation between economic growth and the increasing public debt in Nigeria and other developing countries. However, in the course of this study, available literatures showed that studies on domestic debts in relation to economic development have been relatively revealing for Nigeria. 
The work of Onyeiwu (2012) investigated the relationship between domestic debt and economic growth in the period spanning from year 1994 to 2008 . The study found that domestic debt stock holding by government to was far above a vigorous threshold of 35 percent of bank deposit, in so doing providing evidence of private investment crowd-out in addition to adverse growth effect during the period of investment.

Peter, Dennis \& Chukwuedo (2013) investigated the connection between government domestic debt and economic growth of Nigeria. In their findings, domestic debt and credit had significant and positive relationships with GDP, while debt servicing had negative relationship with GDP. In addition, government expenditure had a positive but insignificant relationship with GDP.

The empirical work of Damian \& Chukwunonso (2014) dealt on the issues concerning the structure and composition of domestic debt and its impact on private investment in Nigeria employed multiple regression models and data from 1970 to 2012. The study established that domestic debt had a significant negative impact on domestic private investment in Nigeria. It was also seen from the study that domestic debt had a significant negative impact on foreign private investment in Nigeria with exchange rate and debt servicing showing positive effect on foreign private investment in Nigeria.

Ozurumba \& Kanu in their study in 2014 on the impact of different components of domestic debt on economic growth of Nigeria found that in the short-run, FGN Bond showed a positive significant association with economic growth, whereas development stock had significant but negative relationship. However, Treasury Bills and the lagged value of GDP variables were positively significant in the long-run.

ThankGod (2014) assessed the implications of public debt on private investment in Nigeria over the period 1981 - 2012. The study made use of the instrumental variable technique of estimation and bootstrapping technique for the computation of normal based standard errors for the turning points. The results discovered that domestic debt had a linear and positive impact on private investment; external debt had a U-shaped impact on private investment; and private consumption expenditure had a negative impact on private investment. The external debt turning point was estimated to be 124.69 percent and was statistically significant at the $1 \%$ level.

Mohammed, Mahfuzul \& Igwike (2015) studied the connection between economic growth and debt, they employed many advanced econometric tools to investigate the effect of government borrowing on national output in 48 countries of Sub Saharan Africa from 1995-2012. The findings exhibited proof of economic linkage among public debt and national output in eight economies from the forty-eight economies. The study agrees with the debt Lafer Curve theory. The study also found that economic association existed between public debt variables and national productivity. The research concluded that there is a connection between politics and physical policy and recommended the necessity to consider the impact of policy implementation on the growth of the economy. In the view of the study the capability of government to arouse growth is highly limited in addition to the fact that if government borrowing becomes high it will distress the economy. Onogbosele \& Ben (2016) in their study investigated the effect of domestic debt on economic growth of Nigeria for the period spanning 1985 to 2014. The study made use of the Vector Autoregression method of analysis. The findings of the study exposed that domestic debt played an important role in the growth process of Nigerian economy. The variance decomposition analysis showed that federal government of Nigeria bonds puts more pressure on the growth rate of gross domestic product in Nigeria. This was trailed by shocks received from treasury bonds, while development stocks and interest rate contributed the least to shocks in gross domestic product. The findings of the impulse response function in support of the variance decomposition analysis revealed that economic growth reacted positively to shocks in federal government of Nigeria bonds and adversely to shocks in treasury bonds throughout the ten-year period. However, the response of gross domestic product to shocks in development stocks and interest rate was not stable.

Igberi, Odo, Anoke \& Nwachukwu (2016) examined the impact of growing government borrowing on the rate of unemployment in Nigeria for a period spanning 1980 to 2015. The study adopted ARDL approach and Wald test statistical procedure in their analysis. The results discovered a stable long-run equilibrium relationship between government borrowings and the rate of unemployment. According to the findings of the research, there was a positive and significant relationship between government borrowing and 
unemployment, and a negative relationship between growth rate of GDP and the rate of unemployment. Moreover, an inverse relationship was also recognized by the study between inflation and unemployment. The study concluded that public debt had no significant effect in Nigerian economy considering that rising public debt had not reduced the rate of unemployment. According to the study, rising debt repayment interest has become an issue in implementing new projects in the economy which has also contributed to a upsurge in the rate of unemployment.

The work of Okwu et al (2016) employed relevant econometric models to examine the effects of domestic debt on economic growth in Nigeria during the 1980 to 2015 periods. Variables of analytic interest were real gross domestic product (RGDP) as economic growth proxy, and domestic debt stock (DDS) and domestic debt servicing expenditure (DDSE) as explanatory variables; with government expenditure (GEXP) and banks' lending rates (BLR) as moderating variables. On individual merits of the explanatory variables, the results presented evidence of significant short- and long-run positive effect for DDS; negative effect for DDSE but insignificant, and negative effect for BLR. The variables jointly explained significant effect, and considerably high power in explaining variations in growth of the economy during the period of the study.

Bakare, Ogunlana, Adeleye \& Mudasiru (2016) in their empirical study investigated the extent to which domestic debt influence the economic growth of Nigeria. It draws on quantitative research methodological framework and specifically employed the Ordinary Least Square Regression (OLS) technique to test the relationship between Gross Domestic Product, interest rate, domestic debt, budget deficit and domestic credit to private sector. Findings of the study revealed that there was a positive relationship between domestic debt and economic growth of Nigeria.

Ewubara, Nteegah \& Okpoi (2017) examined the effect of public borrowing on growth of the Nigerian economy over the period 1980-2015. The study employed the ARDL method in the analysis. The result of the study indicated that external debt had direct and significant impact of growth, while domestic debt significantly retarded growth in Nigeria both in the long and short runs. Total debt services stock was found to negative and insignificant to the economic growth, whereas net foreign direct investment and foreign exchange reserves impacted on economic growth positively and was both significant at 5\% level at lag 3 . Though the goodness of fit was robust and reasonable in explaining changes in growth, the non-significance of the error correction term implies that economic growth reacts slowly to changes in public debts dynamics in Nigeria.

Akhanolu, Babajide \& Akinjare (2018) in their joint study examined the implications of government's debt on economic growth from 1982 to 2017. The study used two-stage least square regression. The result showed that internal debt positively affects the economy. The study is consistent with the study of Tamunonimim (2013) who investigated the relationship between domestic debt and the rate of poverty in Nigeria and found that long-run relationship exist between poverty and domestic debt in Nigeria. He also found that the domestic debt had positive impact on bank credit and the impact is highly significant.

\section{Methodology}

The present study adopted an ex-post-facto research design .It intends to determine the effect of ever rising Nigerian domestic debt on the economic development from 1981-2018. This period covered the times domestic borrowing witnessed tremendous increment and robust activities in the budget deficit financing. Secondary data were used, and collected from various sources including Central Bank of Nigerian Statistical Bulletin, Securities and Exchange Commission Statistical Bulletin, Debt Management Office of Nigeria, World Bank Development Indicators and United Nations Development Program from 1981 - 2018. The explanatory variables include Federal domestic debt, State domestic debt and domestic debt servicing, while the dependent variables are credit to private sector (CPS) and Human Development Index (HDI).

\subsection{Model Specification}


The two independent variables of Human Development Index as proxy for economic development and Credit to Private Sector as proxy for private sector investment and its attendant crowding out effect led to the formulation of two variables.

\section{The Functional Model One for Estimation}

HDIt $=\mathrm{f}(\mathrm{FDDt}$, SDDt, DDSt $) \ldots . .$. Equation 3.1

In order to capture the effect of the random term ' $U$ ' in a parametric form, the equation is stated as follows: HDIt $=\beta 0+\beta 1$ FDDt $+\beta 2$ SDDt $+\beta 3$ DDSt + Ut....... Equation 3.2

To enhance estimated model using the ordinary least squares, model 3.2 is transformed into log-linear form as follows:

$\operatorname{lnHDIt}=\beta 0+\beta 1 \operatorname{lnFDDt}+\beta 2 \ln S \mathrm{SDt}+\beta 3 \operatorname{lnDDSt}+3.3$

Where:

HDI = Human Development Index (proxy for economic development), FDD = Federal Domestic Debt, SDD $=$ State Domestic Debt, DDS $=$ Domestic Debt Servicing, $\ln =$ natural logarithms, $\beta 0$ is the intercept and Ut is disturbance term, $\beta 1, \beta 2$ and $\beta 3$ are coefficient of explanatory variables, $t$ is time period under investigation.

Other things being equal, the theoretical a priori expectation is: $\beta 1>0, \beta 2>0, \beta 3<0$,

\section{The Functional Model Two for Estimation}

$\mathrm{CPSt}=\mathrm{f}($ FDDt, SDDt, DDSt $) 3.4$

In order to capture the effect of the random term ' $U$ ' in a parametric form, the equation is stated as follows: $\mathrm{CPSt}=\beta 0+\beta 1 \mathrm{FDDt}+\beta 2 \mathrm{SDDt}+\beta 3 \mathrm{DDSt}+\mathrm{Ut} 3.5$

To enhance estimated model using the ordinary least squares, model 3.5 is transformed into log-linear form as follows:

$\operatorname{lnCPSt}=\beta 0+\beta 1 \operatorname{lnFDDt}+\beta 2 \operatorname{lnSDDt}+\beta 3 \ln D D S t+\mathrm{Ut} 3.6$

Where:

CPS $=$ Credit to Private Sector (proxy for Private Investment), FDD $=$ Federal Domestic Debt, SDD $=$ State Domestic Debt, DDS $=$ Domestic Debt Servicing, $\ln =$ natural logarithms, $\beta 0$ is the intercept and Ut is disturbance term, $\beta 1, \beta 2$ and $\beta 3$ are coefficient of explanatory variables, $t$ is time period under investigation. Other things being equal, the theoretical a priori expectation is: $\beta 1>0, \beta 2>0, \beta 3<0$.

\section{Analysis and Results}

\subsection{Result of Unit Root Test}

It is almost a convention in time series analysis, to verify the order of integration for each series to avoid the problem of spurious regression (Granger and Newbold, 1997; Phillips 1987). Unit root test was conducted mainly to determine whether or not variables are stationary at zero order I( 0$)$, first order I(1) or second order I(2). The test was carried out with the instrument of Augmented Dickey-Fuller unit root and the results tabulated in 4.1 below.

Table 4.1: Augmented Dickey-Fuller Unit Root Test

\begin{tabular}{|c|c|c|c|c|c|}
\hline Variables & Stages & $\begin{array}{c}\text { ADF } \\
\text { Statistics }\end{array}$ & $\begin{array}{c}\text { Critical } \\
\text { Values @ 5\% }\end{array}$ & $\begin{array}{c}\text { Order of } \\
\text { Integration }\end{array}$ & Decision \\
\hline HDI & At Levels & -1.1324 & -2.9434 & & $\begin{array}{c}\text { Non- } \\
\text { Stationary }\end{array}$ \\
\hline HDI & $\begin{array}{c}\text { First } \\
\text { Differencing }\end{array}$ & -4.2186 & -2.9458 & $1(1)$ & Stationary \\
\hline CPS & At Levels & -0.6535 & -2.9458 & & $\begin{array}{c}\text { Non- } \\
\text { Stationary }\end{array}$ \\
\hline CPS & $\begin{array}{c}\text { First } \\
\text { Differencing }\end{array}$ & -4.1081 & -2.9458 & $1(1)$ & Stationary \\
\hline
\end{tabular}


${ }^{1}$ Opara Ihunna Victoria, ${ }^{2}$ Nzotta Samuel Mbadike and ${ }^{3}$ Kanu Success Ikechi

Nigeria's Domestic Public Debts and Economic Development

\begin{tabular}{|c|c|c|c|c|c|}
\hline FDD & At Levels & -1.8878 & -2.9434 & & $\begin{array}{c}\text { Non- } \\
\text { Stationary }\end{array}$ \\
\hline FDD & $\begin{array}{c}\text { First } \\
\text { Differencing }\end{array}$ & -4.4579 & -2.9458 & $1(1)$ & Stationary \\
\hline DDS & At Levels & -4.0224 & -2.9434 & $1(0)$ & Stationary \\
\hline SDD & At Levels & -0.3652 & -2.9434 & & $\begin{array}{c}\text { Non- } \\
\text { Stationary }\end{array}$ \\
\hline SDD & $\begin{array}{c}\text { First } \\
\text { Differencing }\end{array}$ & -9.0902 & -2.9458 & $1(1)$ & Stationary \\
\hline
\end{tabular}

Source: Researcher's Summary from Eview Statistical Package Ver. 9.0.

The result of the Augmented Dickey-Fuller unit root test presented in Table 4.1 above revealed that at 5\% critical value, domestic debt services is stationary at zero order of integration, $1(0)$ whereas human development index, credit to private sector, federal domestic debt and state domestic debt were stationary at first differencing.

\subsection{Result of Model One (Human Development Index)}

\subsubsection{Johansen Cointegration Test}

Since the variables are not integrated at zero order $\mathrm{I}(0)$, it means that long-run equilibrium relationship may exist in the data set. Hence we carried out the cointegration test to validate or nullify our claim. The results of the Johansen Cointegration Test (Trace and Maximum Eingen Value Test) are presented in Table 4.2 and 4.3:

Table 4.2: Cointegration Test (Trace Statistic)

Unrestricted Cointegration Rank Test (Trace)

\begin{tabular}{ccccc}
\hline \hline $\begin{array}{c}\text { Hypothesized } \\
\text { No. of CE(s) }\end{array}$ & Eigenvalue & $\begin{array}{c}\text { Trace } \\
\text { Statistic }\end{array}$ & $\begin{array}{c}0.05 \\
\text { Critical Value }\end{array}$ & Prob.** \\
\hline \hline None $^{*}$ & 0.427033 & 39.98494 & 47.85613 & 0.2231 \\
Atmost 1 & 0.317820 & 19.93556 & 29.79707 & 0.4272 \\
Atmost 2 & 0.136713 & 6.166951 & 15.49471 & 0.6758 \\
Atmost 3 & 0.024003 & 0.874660 & 3.841466 & 0.3497 \\
\hline \hline
\end{tabular}

Trace test indicates no cointegrating eqn(s) at the 0.05 level

The result of the cointegration test presented in Table 4.2 showed that at $5 \%$ critical value, none of the series are cointegrated. This means that long-run equilibrium relation may not exist among the variables; hence we accept the null hypothesis of no cointegration.

Table 4.3: Cointegration Test (Max-Eingen Value Statistic)

Unrestricted Cointegration Rank Test (Maximum Eigenvalue) 
${ }^{1}$ Opara Ihunna Victoria, ${ }^{2}$ Nzotta Samuel Mbadike and ${ }^{3}$ Kanu Success Ikechi

Nigeria's Domestic Public Debts and Economic Development

\begin{tabular}{ccccc}
\hline \hline $\begin{array}{c}\text { Hypothesized } \\
\text { No. of CE(s) }\end{array}$ & Eigenvalue & $\begin{array}{c}\text { Max-Eigen } \\
\text { Statistic }\end{array}$ & $\begin{array}{c}0.05 \\
\text { Critical Value }\end{array}$ & Prob.** \\
\hline \hline None & 0.427033 & 20.04938 & 27.58434 & 0.3377 \\
At most 1 & 0.317820 & 13.76861 & 21.13162 & 0.3843 \\
At most 2 & 0.136713 & 5.292291 & 14.26460 & 0.7046 \\
At most 3 & 0.024003 & 0.874660 & 3.841466 & 0.3497 \\
\hline \hline
\end{tabular}

Max-eigenvalue test indicates no cointegration at the 0.05 level

The statistic in Table 4.3 showed that at 5\% Critical Value, no cointegrating equations exist in the series. This means that long-run equilibrium relation may not exist among the variables; hence we equally accept the null hypothesis of no cointegration.

\subsubsection{Least Square Regression for Model One}

Table 4.4 below presents Least Square Regression result for model one.

\section{Dependent Variable: HDI}

Sample: 19812018

Included observations: 38

\begin{tabular}{crlrr}
\hline \hline \multicolumn{1}{c}{ Variable } & Coefficient & Std. Error & t-Statistic & Prob. \\
& & & & \\
\hline \hline C & -0.923275 & 0.047180 & -19.56941 & 0.0000 \\
FDD & 0.014777 & 0.013273 & 1.113348 & 0.2734 \\
DD S & -0.018856 & 0.008896 & -2.119513 & 0.0414 \\
SDD & 0.032717 & 0.005139 & 6.366302 & 0.0000 \\
& & & & \\
\hline \hline & 0.959387 & Mean dependent var & -0.829553 \\
R-squared & 0.955804 & S.D. dependent var & 0.125165 \\
Adjusted R-squared & 0.026313 & Akaike info criterion & -4.338183 \\
S.E. of regression & 0.023541 & Schwarz criterion & -4.165806 \\
Sum squared resid & 86.42548 & Hannan-Quinn criter. & -4.276853 \\
Log likelihood & 267.7251 & Durbin-Watson stat & 1.853059 \\
F-statistic & 0.000000 & & \\
Prob(F-statistic) & & & & \\
\hline \hline
\end{tabular}

Source: Eview 9.0 Statistical Package

From the results above, it can be seen that three explanatory variables were regressed against the controlled variable (Human Development Index) and the result are stated in Table 4.4 equation 4.1 as follows:

HDI $=\mathbf{- 0 . 9 2 3}+\mathbf{0 . 0 1 4 8 F D D}-\mathbf{0 . 0 1 8 9 D D S}+\mathbf{0 . 0 3 2 7 S D D}$

$$
\begin{array}{lllll}
(4.1) & (0.0000) & (0.2734) & (0.0414) & (0.0000)
\end{array}
$$

NB: the p-values are in parentheses. 


\section{${ }^{1}$ Opara Ihunna Victoria, ${ }^{2}$ Nzotta Samuel Mbadike and ${ }^{3}$ Kanu Success Ikechi}

Nigeria's Domestic Public Debts and Economic Development

From the model above, it is apparent that the constant parameter $(\beta 0)$ is negatively related to economic development at -0.923 with probability value of 0.0000 which is less than $5 \%$ critical value. This is a signal that development of Nigerian economy will decrease by 923million naira when the explanatory variables are held constant.

It is also evident in the result above that federal domestic debt and state domestic debt have positive coefficients, whereas domestic debt services has negative coefficients which are in conformity with the a priori expectations of the study. Quantitatively, a unit increase in federal domestic debt and state domestic debt will increase human development index by 0.0148 and 0.0327 . Conversely, a unit increase in domestic debt servicing will decrease economic development by 0.0189 .

Furthermore, the F-statistic value of 267.7251 with its probability value of 0.000000 revealed a robust and reliable model. In order words, the explanatory variables are jointly significant in predicting the development of Nigerian economy. Also, R-squared of 0.9594 signify that the independent variables explained about 95.94\% variations in human development index, while the remaining $4.06 \%$ is accounted for by stochastic variables. Additionally, the adjusted R-square of $95.58 \%$ strongly indicates a well fitted and robust model. These statistics imply that the model is well fitted and dependable in making informed decisions.

The evaluation of the explanatory variables revealed that the respective probability values of domestic debt services and state domestic debt are 0.0414 and 0.0000 which are less than the $5 \%$ critical probability value. The resultant implication of these statistics is that these variables are strongly related to economic development of Nigeria. However, domestic debt service is negatively related to the independent variable.

\subsection{Result of Model Two (Private Sector Investment)}

\subsubsection{Johansen Cointegration Test}

Since the variables are not integrated at zero order $\mathrm{I}(0)$, it means that long-run equilibrium relationship may exist in the data set. Hence we carried out the co integration test to validate or nullify our claim. The results of the Johansen Cointegration Test (Trace and Maximum Eingen Value Test) are presented in Table 4.5 and 4.6:

Table 4.5: Cointegration Test (Trace Statistic)

Unrestricted Cointegration Rank Test (Trace)

\begin{tabular}{ccccc}
\hline \hline $\begin{array}{c}\text { Hypothesized } \\
\text { No. of CE(s) }\end{array}$ & Eigenvalue & $\begin{array}{c}\text { Trace } \\
\text { Statistic }\end{array}$ & $\begin{array}{c}0.05 \\
\text { Critical Value }\end{array}$ & Prob.** \\
\hline \hline None & 0.482336 & 43.66383 & 47.85613 & 0.1172 \\
At most 1 & 0.243639 & 19.96035 & 29.79707 & 0.4255 \\
At most 2 & 0.141175 & 9.907833 & 15.49471 & 0.2879 \\
At most 3 & 0.115761 & 4.429008 & 3.841466 & 0.0353 \\
\hline \hline
\end{tabular}

Trace test indicates no cointegration at the 0.05 level

The result of the cointegration test presented in Table 4.5 showed that at $5 \%$ Critical Value, no series is cointegrated. This means that long-run equilibrium relation may not exist among the variables; hence we accept the null hypothesis of no cointegration.

Table 4.6: Cointegration Test (Max-Eingen Value Statistic)

Unrestricted Cointegration Rank Test (Maximum Eigenvalue) 
${ }^{1}$ Opara Ihunna Victoria, ${ }^{2}$ Nzotta Samuel Mbadike and ${ }^{\mathbf{3}}$ Kanu Success Ikechi

Nigeria's Domestic Public Debts and Economic Development

\begin{tabular}{ccccc}
\hline \hline $\begin{array}{c}\text { Hypothesized } \\
\text { No. of CE(s) }\end{array}$ & Eigenvalue & $\begin{array}{c}\text { Max-Eigen } \\
\text { Statistic }\end{array}$ & $\begin{array}{c}0.05 \\
\text { Critical Value }\end{array}$ & Prob.** \\
\hline \hline None & 0.482336 & 23.70347 & 27.58434 & 0.1454 \\
At most 1 & 0.243639 & 10.05252 & 21.13162 & 0.7397 \\
At most 2 & 0.141175 & 5.478825 & 14.26460 & 0.6806 \\
At most 3* & 0.115761 & 4.429008 & 3.841466 & 0.0353 \\
\hline \hline
\end{tabular}

Max-eigenvalue test indicates no cointegration at the 0.05 level

The statistic in Table 4.6 showed that at 5\% Critical Value, no cointegrating equations exist in the series. This means that long-run equilibrium relation may not exist among the variables; hence we equally accept the null hypothesis of no cointegration.

4.3.2 Least Square Regression for Model Two

Table 4.7 below presents Least Square Regression result for model one.

Dependent Variable: CPS

Sample: 19812018

Included observations: 38

\begin{tabular}{lrlrr}
\hline \hline \multicolumn{1}{c}{ Variable } & Coefficient & Std. Error & t-Statistic & Prob. \\
& & & & \\
\hline \hline C & 0.244838 & 0.589198 & 0.415545 & 0.6804 \\
FD & 0.764889 & 0.165757 & 4.614520 & 0.0001 \\
DD S & -0.038341 & 0.111103 & -0.345095 & 0.7321 \\
SDD & 0.359238 & 0.064180 & 5.597385 & 0.0000 \\
& & & & \\
\hline \hline & 0.986419 & Mean dependent var & 6.231655 \\
R-squared & 0.985221 & S.D. dependent var & 2.703081 \\
Adjusted R-squared & 0.328612 & Akaike info criterion & 0.711422 \\
S.E. of regression & 3.671515 & Schwarz criterion & 0.883799 \\
Sum squared resid & -9.517011 & Hannan-Quinn criter. & 0.772752 \\
Log likelihood & 823.1779 & Durbin-Watson stat & 0.859621 \\
F-statistic & 0.000000 & & \\
Prob(F-statistic) & & & \\
& & & & \\
& & & & \\
\end{tabular}

Source: Eview 9.0 Statistical Package

From the results above, it can be seen that three explanatory variables were regressed against the controlled variable (Credit to Private Sector) and the result are stated in Table 4.7 equation 4.2 as follows:
HDI $=0.2448+0.765 F D D-0.0383 D D S+0.359 S D D$
Equation 4.2
$(0.6804)$
$(0.0001)$
$(0.7321)$
$(0.0000)$

NB: the p-values are in parentheses. 
From the model above, it is apparent that the constant parameter $(\beta 0)$ is positively related to credit to private sector with 0.2448 with probability value of 0.6804 which is greater than $5 \%$ critical value. This is a signal that private sector debt will decrease by 244.8 million naira when the explanatory variables are held constant. It is also evident in the result above that federal domestic debt and state domestic debt have positive coefficients, whereas domestic debt services has negative coefficients which are in conformity with the a priori expectations of the study. Quantitatively, a unit increase in federal domestic debt and state domestic debt will increase human development index by 765 and 359million naira respectively. Conversely, a unit increase in domestic debt servicing will decrease credit to private sector by 38.3 million naira.

Furthermore, the F-statistic value of 823.18 with its probability value of 0.000000 revealed a robust and strong econometric model. In order words, the explanatory variables are jointly significant in predicting the private sector investment in Nigeria. Also, R-squared of 0.9864 signify that the independent variables explained about $98.64 \%$ variations in private sector investment, while the remaining $1.36 \%$ is accounted for by stochastic variables. Additionally, the adjusted R-square of $98.52 \%$ strongly indicates a well fitted and robust model. These statistics imply that the model is fit and dependable in making informed decisions.

Addedly, the evaluation of the explanatory variables revealed that the respective probability values of federal domestic debt and state domestic debt are 0.0001 and 0.0000 which are less than the $5 \%$ critical probability value. The resultant implication of these statistics is that these variables are strongly related to private sector investment in Nigeria, hence domestic public debt have no crowding-out effect on private investment. However, domestic debt service is negatively related to the independent variable.

\subsection{Summary of Findings}

This study revealed significant policy issues which are considered consequential in decision making in the public sector financial management in Nigeria. Details of the outcome of the study revealed that federal domestic debt is significantly related to private sector investment. This is not surprising given that the borrowed funds are still circulating within the economy and constitute the aggregate national income and consumption. Domestic borrowing is an instrument of economic stabilization and most times, a source of financing budget deficit and other developmental programs of the government.

Domestic Debt servicing is negatively related to economic development and private sector debts respectively in Nigeria. This finding is in tandem with our theoretical expectation and is also consistent with previous researches of Seetanah, Radachi and Durbary (2007); Hammed, Ashraf and Chaudhary (2008); Peter, Dennis and Chukwuedo (2013) respectively. This is a clear evidence of outflows in the economy where by the funds that ordinarily could have been invested within the economy were channeled in servicing debt which constitute economic leakage, stalling the growth of the economy. The resultant effect is seen in the poor quality of life, rising unemployment, high mortality rate, low life expectancy, poor quality education, etc. among the citizens.

Furthermore, State Domestic Debts are positively and significantly related to economic development according to Abbas (2004), and private sector investment respectively in line with the theoretical expectations. This is clear evidence that government spending has little or no crowding-out effect on the private sector. It also went ahead to confirm that government spending at the sub-national level of governance have greater impact on expanding the space for private investment to thrive.

\subsection{Concluding Remarks}

Economic development theories strongly support and recommend that borrowing for investment smoothens the progress of economic development especially in less developed economies. Nigerian economy has mostly been modeled and planned its fiscal policies leveraging on the support of borrowed funds. Interestingly, the findings of this study indicate that these funds have promoted economic development in Nigeria, as it was shown that domestic borrowings positively and significantly impacted on the Human Development Index. However, borrowing by the government to finance development programs is not an end but the ability of the government to pay back or service the debt. According to the findings of this study, it is the major problem 
being faced by Nigeria given that the repayments of debts constitute a big leakage and suffocates the sustainability of economic gains especially at the sub-national levels. Findings further revealed that the poor management of borrowed funds by state government is worrisome because the repayment constitutes significant leakage in the required funds for investment and implementation of government programs. The implication of this is that state government lacks capacity to profitably manage public funds especially borrowed ones.

It is also noteworthy that the ever increasing debt servicing crowd-out private investment which is inimical in attaining the required development. However, it was discovered in this study that government spending have little or no effect on private investment. That makes it obvious that private sector can freely mobilize every required funds for investment without interference or influence from the government. For Nigeria to experience comprehensive development, a robust private sector is vital, thus making the non-crowding-out of private investment critical, priority and inevitable.

\subsection{Recommendations}

In conformity with the findings of this study, the following were recommended for economic management and policy making in Nigeria on better ways to implement programmes that will enhance the development of the economy.

i. Given that domestic borrowed funds significantly impact on economic development, it is important that Nigeria should viably leverage on borrowed funds specially to bridge the savings-investment gap.

ii. The resultant effect of domestic borrowed funds has not really crowded out private investment in Nigeria. It is therefore necessary that government and policy managers should sustain this gain, as no economy can thrive without private investment.

iii. Government should as a matter of urgency begin the process of diversifying the economic base of the country which will bring up new revenue sources and avoid over reliance on borrowings to finance its deficits.

iv. The rise in domestic debt profile in Nigeria is attributed to government extra budgetary activities, which most often are not used for the intended project. Commitment to the provisions of the budget and fiscal discipline should be encouraged on the part of the government and its agencies.

v. The government and the Debt Management Office should draw up guidelines to limit the growth of future domestic debt. Effective mechanism should be put in place to ensure that any new borrowing is judiciously utilized to contribute to economic growth.

\section{References}

- Abbas, A. \& Christensen, J. (2007). The Role of Domestic Debt markets Economic Growth: An Empirical Investigation for Low-income Countries and Emerging Markets. IMF Working Paper No. 07/127. CrossRef

- Abbas, S.M.A. (2005). Public Debt Sustainability and Growth in Sub-Saharan Africa (PostHIPC): The Role of Domestic Debt, GDN Project on the Macroeconomics of Low Income Countries, Oxford University and State Bank of Pakistan, February.

- Adofu, I. \& Abula, M. (2010). Domestic Debt and the Nigerian Economy. Current Research Journal of Economic Theory. 2(1), 22-26.

- Akhanolu, I.A., Babajide, A.A. \& Akinjare, V. (2018). The Effect of Public Debt on

- Akram, W. (2010). Impact of Public Debt on the Economic Growth of Pakistan. Centre for Poverty Reduction and Social Policy Development, IsLambad. 
- Alison, J. (2003). Key issues for analyzing domestic Debt sustainability. Debt Relief International Publication.

- Anyanfo, (1993). Public Finance in a Developing Economy - the Nigerian Case, Enugu

- Bakare, I.O.A., Ogunlana, O.F., Adeleye, O. \& Mudasiru, A. (2016). Empirical Analysis of the Effects of Domestic Debt on Nigerian Economic Growth. International Journal of Social Sciences and Humanities Reviews, 6(1), $40-50$.

- Damian, K.U. \& Chukwunonso, S.E. (2014). Domestic Debt and Private Investment in Nigeria. International Journal of Science and Education, 8(2), 2321-7545.

- Economic Growth in Nigeria: An Empirical Investigation". International Business Management 12(6), 436-441.

- Ewubare, D., Nteegah, A. \& Okpoi, G. (2017). Public Borrowing and the Nigerian Economy: An Autoregressive Distributed Lag Model (ARDL) Approach. The International Journal of Social Sciences and Humanities Invention 4(5), 3506-3514.

- Fischer S. \& Easterly, W. (1990). The Economics of the Government Budget Constraint. The World Bank Research Observer 5(2), 127-142 CrossRef

- Gbosi, A.N. (1998). The Impact of Nigeria's Domestic Debt on Macroeconomic Environment. First Bank Review Journal, 24.

- Granger C.W.I. \& Newbold, P. (1997). Spurious Regressions in Econometrics, Journal of Econometrica, 2, 111-120. CrossRef

- Hammed, A.H., Ashraf, A.\& Chaudhary, M.A. (2008). External Debt and its Impact on Economic Growth. International Monetary Fund.

- Igberi, C.O., Odo, S.I., Anoke, C.I. \& Nwachukwu, U.G. (2016). The Implications of Rising Public Debt on Unemployment in Nigeria: An Auto Regressive Distributed Lag Approach. Asian Research Journal of Arts and Social Sciences, 1(1). CrossRef

- IMF (2001) Developing Government Bond Markets: A Handbook (Washington).

- Kehinde, J.S. (2012). Debt and Debt Volatility: Effect on Economic Growth in Nigeria. Asian Economics and Financial Review,2(2), 325-329.

- Kumhof, M. \& Tanner, E. (2005). Government Debt: A Key Role in Financial Intermediation. IMF Working Paper No. 05/57 CrossRef

- Lucy, A., Collins, F.O. \& Ernest, K. A. (2016). The Impact of Government Debt on the Economic Growth of Ghana: A Time Series Analysis. International Journal of Innovation and Economic Development. 2(5), 31-39.

- Nzotta, (2004). Money, Banking and Finance. Owerri ; Hudson-Jude Nigeria Publishers

- Odozi, V.A. (1996). Nigeria's Domestic Public Debt Stock: An Assessment. CBN Debt Trend, 20(2).

- Okon, E.B., Maji, A. \& Dennies, C.A. (2013). The Relative Potency and Domestic Debts on Economic Performance in Nigeria. European Journal of Humanities and Social Sciences, 27(1), 1414-1429.

- Okwu, A.T., Obiwuru, T.C. Obiakor, R.T., \& Oluwalaiye, O.B. (2016). Domestic Debt and Economic Growth in Nigeria: Data-based Evidence. Greener Journal of Economics and Accountancy, 5(1), 001-012. CrossRef

- Onogbosele, D.O. \& Ben, M.D. (2016). The Impact of Domestic Debt on Economic Growth of Nigeria. Asian Research Journal of Art Social Sciences, 1(3), 1-13. CrossRef

- Onyeiwu, C. (2012). Domestic Debt and the Growth of Nigeria Economy. Research Journal of Finance and Accounting, 5(3).

- Oshandami (2006). The Impact of Domestic Debt on Nigeria's Economic Growth. Unpublished B.Sc Project. Department of Economics, Kogi State University, Anyigba 
${ }^{1}$ Opara Ihunna Victoria, ${ }^{2}$ Nzotta Samuel Mbadike and ${ }^{3}$ Kanu Success Ikechi

Nigeria's Domestic Public Debts and Economic Development

- Oyejide, T., Soyode, A. \& Kayode, M.O. (1985). Nigeria and the IMF. African Economic Research Consortium, Research Paper No.8. Initiative Publishers, Initiative Limited, Nairobi.

- Ozurumba, B.A. \& Kanu, S.I. (2014). Domestic Debt and Economic Growth in Nigeria.

- Journal of Economics and Sustainable Development, 1(5).

- Peter, N.M. Denis, N.Y. \& Chukwuedo, S.O. (2013). Analysis of Domestic Debt: Implication for Economic Growth in Nigeria. Global Journal Series, 9(12).

- Phillips, P.C.B. (1987). Testing for Unit Root in Time Series Regression, Cowles Foundation, Yale University. CrossRef

- Seetanah, B., Padachi, K. \& Durbarry, R. (2007). External Debt and Economic Growth: A Vector Error Correction Approach. International Journal of Business Research, 7(5)

- Tajudeen, E. (2012). Public Debt and Economic Growth in Nigeria: Evidence from Granger Causality. American Journal of Economics, 2(6), 101- 106. CrossRef

- Tamunonimim, A.N. (2013). Domestic Debt and Poverty in Nigeria: An Empirical Time Series Investigation. European Journal of Accounting, Auditing and Financial Research, 5(2), 33-47.

- ThankGod, O.A. (2014). The Impact of Public Debt on Private Investment in Nigeria: Evidence from a Nonlinear Model. International Journal of Research in Social Science, 2(4), 1-9.

- Ugwu, O.J. (2017). Imperatives of Domestic Debt Payments and Economic Growth: the Nigerian Evidence, Journal of Economic and Finance (IOSR-JEF), 8(1), 46-51. www.iosrjournals.org. CrossRef 